Original Research Article

\title{
Determinants of Intention to Purchase Halal Cosmetic Products: A Study on Muslim Women in West Malaysia
}

\author{
Chooi Yi Wei ${ }^{1 *}$, Yoke Chin Kuah ${ }^{1}$, Zam Zuriyati Mohamad ${ }^{2}$ \\ ${ }^{1}$ Department of Finance, Faculty of Business and Finance, Universiti Tunku Abdul Rahman, Kampar, Perak, \\ Malaysia \\ ${ }^{2}$ Department of Commerce and Accountancy, Faculty of Business and Finance, Universiti Tunku Abdul \\ Rahman, Kampar, Perak, Malaysia \\ *Corresponding author: Chooi Yi Wei, Department of Finance, Faculty of Business and Finance, Universiti \\ Tunku Abdul Rahman, Kampar, Perak, Malaysia; weicy@utar.edu.my
}

\begin{abstract}
The demand for the global halal cosmetics market is anticipated to reach USD 53 billion by the end of 2023. The increase of worldwide Muslim population along with their responsiveness to religious obligation, a consciousness of the cosmetic ingredients, process and packaging and the rising awareness about the percutaneous essence of conventional cosmetic products has made purchasers shift to "halal" cosmetics. Malaysia is one of the countries that provides full support to promote the "halal" certification process. Products certified "halal" by JAKIM are Halal products as they are safe to purchase, nutritious and the products are quality controlled. Parallel to that, the purpose of this research is to determine the halal cosmetic purchase intention among Muslim women in West Malaysia. As aforementioned, this study has identified five factors that influence purchasers' intention in purchasing halal cosmetic products. These factors served as independent variables namely functional value, conditional value, social value, epistemic value and emotional value which are guided by the Theory of Consumption Value (TCV). This research employed a structured online survey targeting approximately 400 Muslim women from the age of 16 to 60 years old in West Malaysia. Data obtained were analysed using Partial Least Square-Structural Equation Modelling (PLS-SEM). The findings revealed that conditional value, emotional value and epistemic value are positively and significantly related to the halal cosmetic purchase intention. On the other hand, functional value and social value are discovered to be insignificantly related to the intention to purchase halal cosmetic products. Practically, the findings will be beneficial to halal cosmetic manufacturers in determining consumer purchase intention. In terms of socio-economic, this study offers insight on halal cosmetic market and feedback from the Muslim community on halal cosmetic products. Theoretically, this study provides a comprehensive theoretical framework on the intention to purchase halal cosmetic products.
\end{abstract}

Keywords: Halal; cosmetic; knowledge; reliability; Theory of consumption Value (TCV); Theory of Planned Behavioural (TPB)

Received: $18^{\text {th }}$ February 2020

Citation: Wei CY, Kuah YC, and Mohamad ZZ.

Accepted: $20^{\text {th }}$ March 2020

Determinants of Intention to Purchase Halal Cosmetic Products: A Study on Muslim women in West Malaysia. J Halal Ind Serv 2020; 3(1):

Published Online: $2^{\text {nd }}$ April 2020 a0000092. https://doi.org/10.36877/jhis.a0000092 


\section{Introduction}

The Muslim population all over the world is increasing over time. The Muslim population in Malaysia is taking up around $65 \%$ of the total population and is forecasted to be increasing in the future. Owing to this, demands and consumptions of Halal products are also increasing. One of the current demands and consumptions of Halal products is Halal cosmetics (Norafni et al., 2015). In today's world, Muslims comprise one of the biggest world markets for Halal products (Hajipour et al., 2015).

The new term of Halal cosmetics was urbanised in recent years, yet some of the Muslims in Islamic countries including Malaysia are still unfamiliar with these Halal cosmetic products as they only recognise the Halal term just for food and beverage products; not for cosmetic and healthcare products. Previous research has been carried out by Ajitha and Sivakumar (2017), Ambali and Bakar (2014), Aziz and Wahab (2013), Jalil et al. (2018), and Ruslan et al. (2018) on Halal food, but lack of study is focused on Halal cosmetic products which currently catch the purchasers' and manufacturers' attention.

Besides, the attitude to use cosmetics is changing from conventional cosmetic products to halal cosmetic products. At present, most women emphasise the importance of personal grooming. This also includes working women and those who are having higher incomes who often interested to buy cosmetic products (Hassali et al., 2015).

Therefore, this study is carried out to determine the intention of Muslim women in West Malaysia in purchasing Halal cosmetic products.

\section{Halal Cosmetic Industries in Malaysia}

The Halal term refers to what is allowed or permissible by the Shariah law. It is the basic requirement for Muslims to adhere to, which can consist of foods and goods consumed or/and used in daily life. Cosmetic products are also included as the materials, ingredients used, usage of raw materials right up to the marketing, and delivery of products to purchasers must be in halal aspect guidance. It also emphasises the safety and product efficacy evaluation. Thus, halal cosmetic standards, halal certification and halal logo can be applied as guidelines for halal compliances (Hashim \& Mat Hashim, 2013).

Malaysia established the Halal Industry Development Corporation (HDC) to develop and facilitate the halal industry. In fact, manufacturers must follow several requirements that are restricted mostly from the ingredients until the packing to ensure they are categorised as halal products that can be consumed by Muslims (Aziz \& Wahab, 2013).

In 2006, Malaysia started following a holistic approach towards being halal because Malaysia realised that the halal sector would be a new contributing factor for the economic growth in the country. Besides, Malaysia is one of the early countries that moved towards Halal cosmetics. From 2006 to 2010, Malaysia has synchronised its strategies on developing halal products and enhancing the service industries (Salleh \& Hussin, 2013). The growth of halal cosmetic products can be seen from the Malaysian halal cosmetics and personal care export value for 2017 that rose to RM2.9 billion. 


\section{Halal Certification in Malaysia}

Malaysia is the only country that provides full support in promoting halal certification process on its products and services. Halal is urged by the Shariah Law. In Malaysia, the agency which is vital and plays a major role in handling halal certification is the Department of Islamic Development Malaysia (JAKIM). Products certified by JAKIM are halal and safe to purchase as they are also supported for their nutrients and quality (HIDC, 2017).

For cosmetic and personal care products which also require halal certification, the products must comply with the standard of MS 2200:2008 purchaser goods requirements. According to MS 2200:2008 purchaser goods guidelines and requirements, cosmetic products must be safe and non-hazardous to the purchasers.

Apart from it, these products must comply with the Shariah law. In brief, halal cosmetic products should not contain any human parts as ingredients; should not contain any animal that is prohibited to Muslims or has not been slaughtered according to Shariah law; no genetically modified organism (GMO) which is decreed as najs; no alcohols used from alcoholic beverages (khamar); no contamination during preparation, processing, manufacturing and storage, and they should be safe for purchasers (Salleh \& Hussin, 2013). Hence, for halal cosmetic products, the formulation and the quality of the products must comply with the Islamic requirements and also the requirements of the National Pharmaceutical Control Bureau, Ministry of Health Malaysia.

This study is organised in the following manner. The next section includes a literature review followed by the theory of consumption behaviour. Subsequently, it describes the methodology and results of this study. The conclusion is made at the end of this paper.

\section{Literature Review}

This study applied the Theory of Consumption Value (TCV) developed by Sheth et al. (1991) for the formation of the conceptual framework. According to Sheth et al. (1991), the Theory of Consumption Values (TCV) generally explains why purchasers make their choices.

This theory is centrally connected to five main values, specifically via (i) Functional value (ii) Conditional value (iii) Social value (iv) Emotional value and (v) Epistemic value towards purchasing intention on halal cosmetic products. Functional value is acquired from the utilitarian or physical performance, and this is reflected in the characteristics of the products such as the price, durability and reliability of the products.

In a recent paper, Yeo et al. (2016) treated functional value via (i) quality value and (ii) price value. The quality value is articulated by the quality and texture of the cosmetic product itself. Whereas, price value is described as the reference price for customers to consider when buying halal cosmetic products. Similarly, Hashim and Musa (2014) have also found that the price, the content of the products, packaging and Halal logo from JAKIM are the most influencing factors for customers to purchase halal cosmetic products. 
The durability of cosmetic products often refers to the minimum date of the products once unsealed. Furthermore, there are certain conditions such as (i) storing under appropriate conditions (ii) making non-mandatory for products to be used more than 30 months and (iii) labelling using symbols on the "minimum date" + expiry date (month and year, or the day, month and year) also uphold the condition of the products. It is also vital for customers to be aware of the period time after unsealing the products to ensure the products are safe to use without causing harm to the customers. Labadie (2012) suggested that reading the labels of cosmetic products is the best solution to identify if the product complies with the new European Regulation on Cosmetic products which came into effect in 2013.

The reliability of cosmetic products depends on the halal cosmetic certification. Unsurprisingly, Rahman et al. (2015) identified the reliability of halal cosmetic products is highly dependent on the Halal label and Halal logo printed on the outer layer of the products. Annabi and Obe (2017) studied if halal certification assured the quality of halal cosmetic products in the United Kingdom. Unfortunately, the research underpinned that there is a failure to adopt a holistic halal terminology in the industry of halal cosmetics in the United Kingdom. In Malaysia, the reliability of Malaysian Halal Cosmetic products does agree with the Halal Cosmetic Standards as announced by the Malaysian government in June 2010 due to the major concern of Halal Cosmetic Standards which reflects on cosmetic ingredients and materials used in Halal cosmetic products (Aoun \& Tournois, 2015).

Additionally, conditional value derives from a specific condition of using particular products. Baumann (2012) posited that purchasers should avoid buying and using wrong cosmetic products without seeking any advice from cosmetic dermatologists. The drawbacks of using wrong cosmetic products can cause several skin problems such as allergies, melasma, and skin cancer. Nevertheless, in this study, the following indicators are recommended (i) purchasing halal cosmetics for weddings (ii) attending special occasions and (iii) purchasing it as gifts, to be considered as the measurements for conditional value.

Next, social value is identified by demographic factors, cultural influences and socialethnic groups. Ajitha and Sivakumar (2017) revealed social status is symbolised by purchasers' desire to ensure their social presence through the consumption of luxury brands will satisfy their needs to be accepted within professional visibility. Kim et al. (2013) and Rahim et al. (2015) used demographic indicators such as religion, monthly income, monthly spending on cosmetic products and make-up occasions for measuring Halal cosmetic products. In the same vein, Bonne et al. (2007) noticed religion as a very important motivator for the halal cosmetic market. Briliana and Mursito (2017) embraced that religion plays an influential factor that influences customers' attitude and intention in purchasing halal cosmetic products. They also confirmed that multi-religion societies like Indonesian Muslims are more conscious of halal and permitted products. Briliana and Mursito (2017) assessed the cultural factor by using in-depth interviews and surveys for both purchasers and producers. The application of social-ethnic group indicator could be seen in the work by Mukhtar and Butt (2012). Mukhtar and Butt (2012) confirmed the difference between Muslim purchasers and Western purchasers is based on local culture which includes names, symbols and also the particular brands of Halal cosmetic products.

On the other hand, emotional value is associated with the extrinsic aspect of consumption in terms of the ability of the products to affect the buyers' emotional conditions. Thus, our 
studies have identified that the emotional value of purchasers is related to being confident, happy, intelligent, satisfied and also guilty. This can be measured through questionnaire items such as (i) I am happy to use the Halal cosmetic products most of the time (ii) I feel confident to choose Halal cosmetic products (iii) I feel satisfied if I use Halal cosmetics (iv) I make my decision according to my feelings (v) I feel excited to use Halal cosmetic products. Our choices of emotional value indicator were based on the study by Rahman et al. (2015) because of their dependent variable is also into the intention to purchase Halal cosmetic products. This was reflected in their questionnaires for the attitudes towards Halal cosmetics. Questions were asked to the respondents which included (i) I like to choose Halal cosmetic products (ii) I always look for Halal label when I buy cosmetic products (iii) Halal cosmetic products are important (iv) Using Halal cosmetic products is my own choice and (iv) Most people who are important to me use Halal cosmetic products. Rahman et al. (2015) identified the intention in purchasing Halal cosmetic products was mainly derived from the following questions such as (i) I am willing to pay more for cosmetic products with an authentic Halal logo (ii) I am willing to wait longer to buy cosmetic products with an authentic Halal logo (iii) I am willing to shop around to buy cosmetic products with an authentic Halal logo (iv) I am willing to travel a long distance to buy cosmetic products with an authentic Halal logo and (v) I intend to purchase Halal cosmetic products in the near future. Last but not least, epistemic value requires the products to create and arouse curiosity or purchasers' propensity to adopt new products.

Based on the theory, the research framework was formed as Figure 1 below.

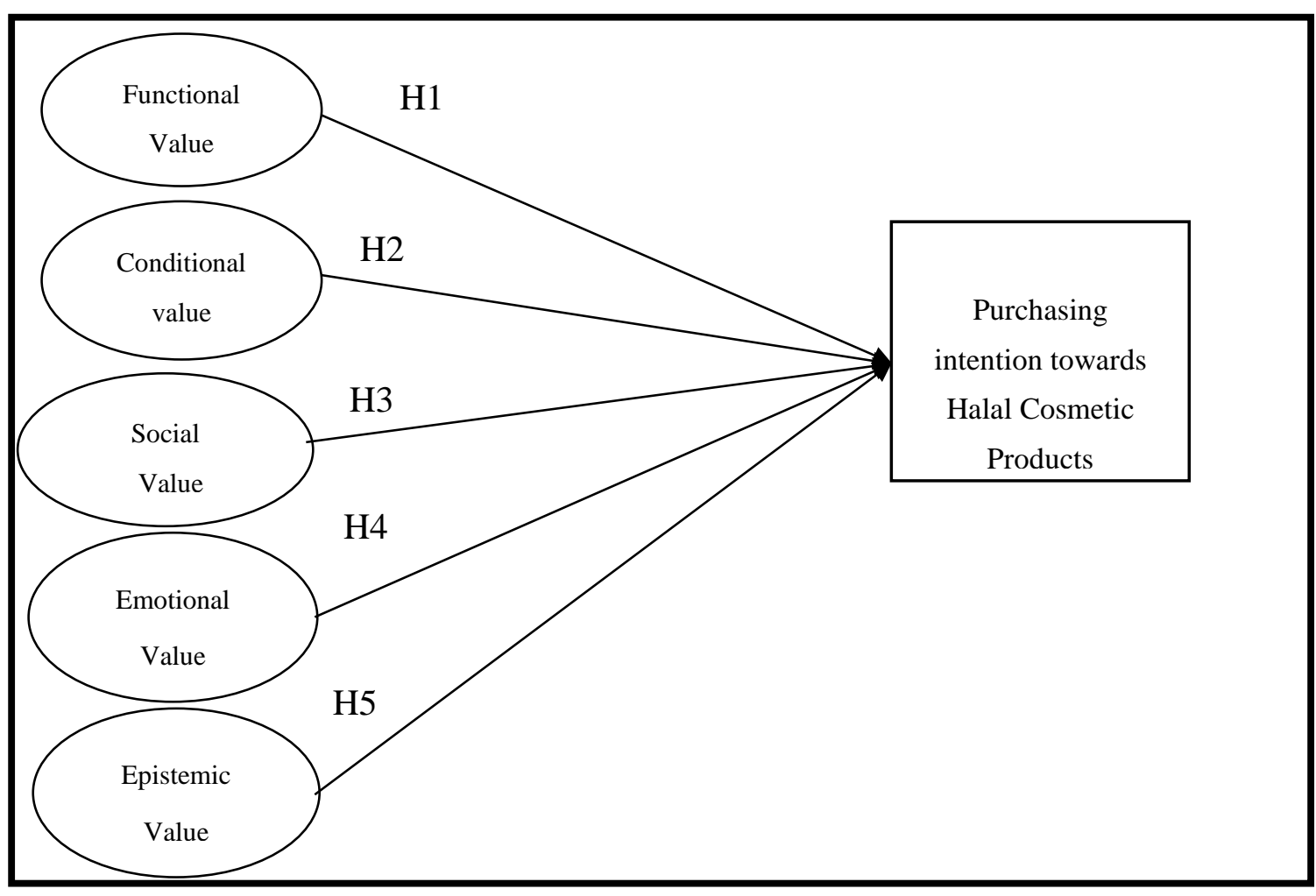

Figure 1. Conceptual Framework 
Thus, the hypotheses were formed as below:

H1: There are significant relationships between functional value and intention in purchasing Halal cosmetic products.

H2: There are significant relationships between conditional value and intention in purchasing Halal cosmetic products.

H3: There are significant relationships between social value and intention in purchasing Halal cosmetic products.

H4: There are significant relationships between emotional value and intention in purchasing Halal cosmetic products.

H5: There are significant relationships between epistemic value and intention in purchasing Halal cosmetic products.

\section{Methodology}

The data were collected through a survey using a structured questionnaire. Academic and admin staff in Universiti Tunku Abdul Rahman (UTAR) carried out the survey. A total of 500 questionnaires was distributed through convenience sampling. As a result, a total of 278 completed questionnaire sets was successfully collected. The gathered questionnaires were keyed in into the SPSS software to access the demographic information of the respondents as summarised in Table 2 . The survey instrument was developed by adopting validated questions used in previous studies which were assessed using the 5-point Likert scale. The questionnaire comprising two sections was used in this study. Section A consists of respondents' details such as age, status, occupation, educational level, income level, monthly expenses on purchasing halal cosmetic products, frequency of buying halal cosmetic products and the duration of usage of these products. Section B consists of 20 measurement items; 3 items for functional value constructs; 3 items for conditional value constructs; 4 items for social value constructs; 4 items for emotional value constructs; 3 items for epistemic value constructs; 3 items for the intention of purchasing halal cosmetic products as dependent variables. All measurement items are explained in Table 1.

\section{Results}

The empirical result consisted of an online survey which obtained 278 total responses from June to October 2018. As shown in Table 2, $64.03 \%$ of the respondents were married ranging from the age of 25 to 38 years old. More than $49 \%$ of respondents hold an executive level with the income of more than RM 4000 per month. These respondents purchase halal cosmetic products more than twice in a year. 
Table 1. Measurement Items

\begin{tabular}{|c|c|c|}
\hline Constructs & Items & \\
\hline \multirow[t]{2}{*}{ Conditional value } & CV1 & I am using Halal cosmetic products for my special occasions. \\
\hline & CV2 & I purchase Halal cosmetic products as gifts. \\
\hline \multirow[t]{4}{*}{ Emotional value } & EM1 & I am happy to use Halal cosmetic products most of the time. \\
\hline & EM2 & I feel confident to choose Halal cosmetic products. \\
\hline & EM3 & I feel satisfied if I use Halal cosmetic products. \\
\hline & EM4 & I make my decision according to my feelings. \\
\hline \multirow[t]{3}{*}{ Epistemic value } & EP1 & It is important for me to know the ingredients of Halal cosmetic products. \\
\hline & EP2 & I will gather reliable information about different Halal cosmetic products before purchasing. \\
\hline & EP3 & I often search for the latest information about Halal cosmetic products. \\
\hline \multirow[t]{2}{*}{ Functional value } & FV1 & Halal cosmetics are perceived to be safe. \\
\hline & FV2 & Some Halal cosmetic products could be purchased online. \\
\hline \multirow[t]{3}{*}{ Intention to Purchase Halal cosmetics } & INT1 & I will try to use Halal cosmetic products in the near future. \\
\hline & INT2 & I like to shop around looking for cosmetic products with an authentic Halal logo. \\
\hline & INT3 & I intend to purchase Halal cosmetic products in the future. \\
\hline \multirow[t]{4}{*}{ Social value } & SV1 & I like the idea of using Halal cosmetic products. \\
\hline & SV2 & People around me will influence my preferences on Halal cosmetic products. \\
\hline & SV3 & I spend little time exploring how to use new Halal cosmetic products. \\
\hline & SV4 & I am hesitant to try out new Halal cosmetic products. \\
\hline
\end{tabular}


Table 2. Descriptive analysis on the respondents' profile

\begin{tabular}{|c|c|c|}
\hline & $\mathbf{N}$ & Percentage \\
\hline \multicolumn{3}{|l|}{ Age } \\
\hline $16-24$ years & 20 & 7.19 \\
\hline $25-31$ years & 80 & 28.78 \\
\hline $32-38$ years & 106 & 38.13 \\
\hline $39-45$ years & 42 & 15.11 \\
\hline $46-50$ years & 18 & 6.47 \\
\hline More than 50 years & 12 & 4.32 \\
\hline \multicolumn{3}{|l|}{ Status } \\
\hline Single & 100 & 35.97 \\
\hline Married & 178 & 64.03 \\
\hline \multicolumn{3}{|l|}{ Highest Education Level } \\
\hline SPM and below & 4 & 1.44 \\
\hline STPM/Diploma & 24 & 8.63 \\
\hline Degree & 112 & 40.29 \\
\hline Master & 118 & 42.45 \\
\hline $\mathrm{PhD}$ & 20 & 7.19 \\
\hline \multicolumn{3}{|l|}{ Monthly Income } \\
\hline Less than RM 1,000 & 14 & 5.04 \\
\hline RM 1,001 - RM 2,000 & 16 & 5.76 \\
\hline RM 2,001 - RM 3,000 & 36 & 12.95 \\
\hline RM 3,001 - RM 4,000 & 50 & 17.99 \\
\hline RM 4,001 - RM 5,000 & 76 & 27.34 \\
\hline RM 5,001 - RM 6,000 & 56 & 20.14 \\
\hline RM 6,000 and above & 30 & 10.79 \\
\hline \multicolumn{3}{|l|}{ Occupation } \\
\hline Student & 14 & 5.04 \\
\hline Housewife & 8 & 2.88 \\
\hline Non-Executive & 78 & 28.06 \\
\hline Executive & 138 & 49.64 \\
\hline Managerial & 40 & 14.39 \\
\hline
\end{tabular}




\begin{tabular}{|c|c|c|}
\hline & $\mathbf{N}$ & Percentage \\
\hline \multicolumn{3}{|c|}{$\begin{array}{l}\text { Monthly expenses for Halal } \\
\text { Cosmetic products }\end{array}$} \\
\hline Less than RM 100 & 128 & 46.04 \\
\hline RM 101 - RM 200 & 96 & 34.53 \\
\hline RM 201 - RM 300 & 40 & 14.39 \\
\hline More than RM 400 & 14 & 5.04 \\
\hline \multicolumn{3}{|c|}{$\begin{array}{l}\text { Frequency of buying Halal } \\
\text { Cosmetic products per year }\end{array}$} \\
\hline 1 & 52 & 18.71 \\
\hline 2 & 38 & 13.67 \\
\hline 3 & 70 & 25.18 \\
\hline 4 & 28 & 10.07 \\
\hline 5 and more & 90 & 32.37 \\
\hline \multicolumn{3}{|l|}{ Duration of usage } \\
\hline Less than 3 months & 48 & 17.27 \\
\hline 3 months -6 months & 110 & 39.57 \\
\hline 6 months -1 year & 62 & 22.3 \\
\hline More than 1 year & 58 & 20.86 \\
\hline
\end{tabular}

Data were analysed and interpreted in two stages. The measurement model was used in the first stage, while the structural model was used in the second stage. The measurement model evaluated the relations between observed items and latent variables. The measurement variable model examined through the assessment of the validity and reliability of the construct measures in the model. This is to ensure that only reliable and validated construct measures were used to assess the nature of relationships in the overall model. 


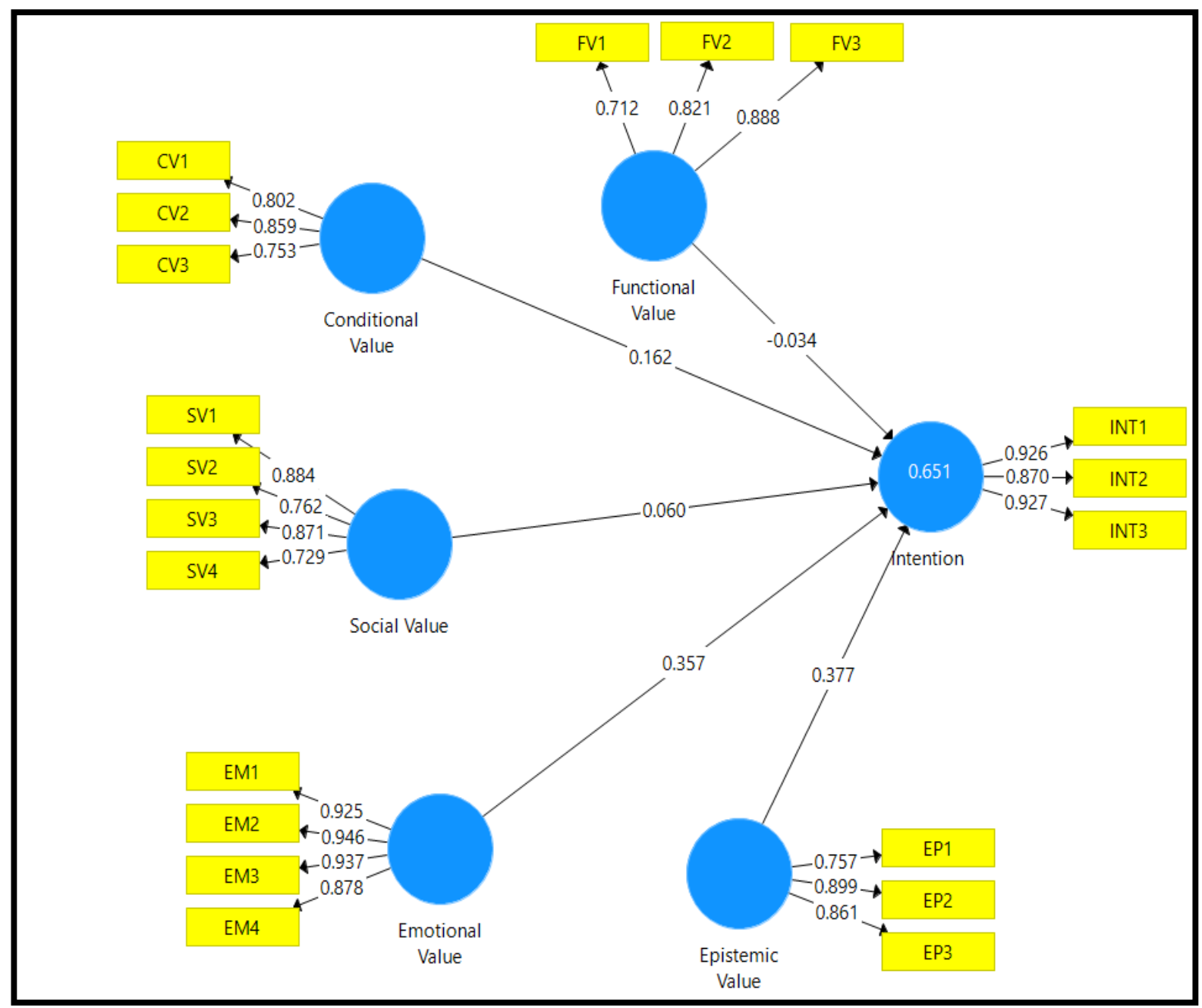

Figure 2. Factor loading in measurement model.

\section{Measurement Model}

\section{Convergent validity}

The convergent validity was tested as it is the agreement to which the multiple items that were used to be measured. As suggested by Hair et al. (2010), factor loading, composite reliability and average variance extracted were the indicators used to access the convergent validity. The loading of all items exceeded the recommended value of 0.6 (Chin et al., 1997). The composite reliability (see Table 3), which is depicted in the degree to which the construct indicator indicated the latent construct, ranged from 0.712 to 0.946 , which exceeded the recommended value of 0.7 (Hair et al., 2010). The average variance extracted, which reflected the overall amount of variance in the indicators accounted by the latent constructs, were in the range of 0.650 to 0.825 , which exceeded the recommended value of 0.5 (Hair $e t$ al., 2010). 
Table 3. Factor loading and reliability

\begin{tabular}{|c|c|c|c|c|}
\hline Items & Factor Loading & $\begin{array}{c}\text { Composite } \\
\text { Reliability }\end{array}$ & $\begin{array}{c}\text { Average } \\
\text { Variance } \\
\text { Extracted }\end{array}$ & $\begin{array}{c}\text { Cronbach } \\
\text { Alpha }\end{array}$ \\
\hline CV1 & 0.802 & 0.847 & 0.650 & 0.729 \\
\hline CV2 & 0.859 & & & \\
\hline CV3 & 0.753 & & & 0.850 \\
\hline EM1 & 0.925 & 0.958 & & \\
\hline EM2 & 0.946 & & & 0.790 \\
\hline EM3 & 0.937 & & & \\
\hline EM4 & 0.878 & & & \\
\hline EP1 & 0.757 & 0.878 & & \\
\hline EP2 & 0.899 & & & \\
\hline EP3 & 0.861 & & & \\
\hline FV1 & 0.712 & 0.850 & & \\
\hline FV2 & 0.821 & & & \\
\hline FV3 & 0.888 & & & \\
\hline INT1 & 0.926 & 0.934 & & \\
\hline INT2 & 0.870 & & & \\
\hline INT3 & 0.927 & & & \\
\hline SV1 & 0.884 & 0.887 & & \\
\hline SV2 & 0.762 & & & \\
\hline SV3 & 0.871 & & & \\
\hline SV4 & 0.729 & & & \\
\hline
\end{tabular}

\section{Discriminant validity}

Discriminant validity is the extent to which the measures do not reflect other variables and it is indicated by low correlations between variables by examining and comparing the average variance extracted (AVE). Based on the formula by Fornell and Larker (1981), it is required that the square root for each construct's average variance extracted (AVE) is to be higher than all its correlation with other constructs. As shown in Table 4, the squared correlations for each construct were less than the square root of the average variance extracted. This further indicated that inferred constructs have a good level of validity. Furthermore, Table 5 below shows the output from heterotrait-monotrait (HTMT) analysis. If the HTMT value is greater than the value of 0.85 (Kline, 2011), there is a problem of discriminant validity. All the HTMT values in Table 5 are below than 0.85 , it shows that collinearity problems are free from this study. 
Table 4. Inter-construct correlation

\begin{tabular}{|c|c|c|c|c|c|c|}
\hline & $\begin{array}{c}\text { Conditional } \\
\text { Value }\end{array}$ & $\begin{array}{c}\text { Emotional } \\
\text { Value }\end{array}$ & $\begin{array}{c}\text { Epistemic } \\
\text { Value }\end{array}$ & $\begin{array}{c}\text { Functional } \\
\text { Value }\end{array}$ & Intention & $\begin{array}{c}\text { Social } \\
\text { Value }\end{array}$ \\
\hline $\begin{array}{c}\text { Conditional } \\
\text { Value }\end{array}$ & 0.806 & & & & & \\
\hline Emotional Value & 0.631 & 0.922 & & & & \\
\hline Epistemic Value & 0.580 & 0.648 & 0.841 & & & \\
\hline $\begin{array}{c}\text { Functional } \\
\text { Value }\end{array}$ & 0.539 & 0.587 & 0.513 & 0.810 & & \\
\hline Intention & 0.620 & 0.727 & 0.719 & 0.489 & 0.908 & \\
\hline Social Value & 0.535 & 0.738 & 0.579 & 0.555 & 0.609 & 0.814 \\
\hline
\end{tabular}

Table 5. HTMT results

\begin{tabular}{|l|c|c|c|c|c|c|}
\hline & $\begin{array}{c}\text { Conditional } \\
\text { Value }\end{array}$ & $\begin{array}{c}\text { Emotional } \\
\text { Value }\end{array}$ & $\begin{array}{c}\text { Epistemic } \\
\text { Value }\end{array}$ & $\begin{array}{c}\text { Functional } \\
\text { Value }\end{array}$ & Intention & $\begin{array}{c}\text { Social } \\
\text { Value }\end{array}$ \\
\hline $\begin{array}{l}\text { Conditional } \\
\text { Value }\end{array}$ & & & & & & \\
\hline Emotional Value & 0.763 & & & & & \\
\hline Epistemic Value & 0.767 & 0.754 & & & & \\
\hline Functional Value & 0.727 & 0.700 & 0.666 & & & \\
\hline Intention & 0.762 & 0.793 & 0.842 & 0.585 & & \\
\hline Social Value & 0.673 & 0.823 & 0.703 & 0.675 & 0.690 & - \\
\hline
\end{tabular}

\section{Structural Model}

Once the reliability and the validity of the measures were assured, the path coefficients were reported based on the results of a PLS structural model. Table 6 shows the significance in the path coefficients. The t-value can be compared with the critical value from the standard normal distribution to decide if the coefficients are significantly different from zero. For instance, the critical value for significant levels of $5 \%$ probability of error is 1.96 (two-tailed test). In this study, the results revealed that conditional value, emotional value and epistemic value significantly affected the intention of purchasing halal cosmetic products. 
Table 6. Summary of the structural model

\begin{tabular}{|l|c|c|c|c|}
\hline Description & Hypothesis & Path Coefficient & $\begin{array}{c}\text { T- } \\
\text { Value }\end{array}$ & Result \\
\hline Functional Value -> Intention & H1 & -0.034 & 0.677 & Not supported \\
\hline Conditional Value -> Intention & H2 & 0.162 & $3.294^{*}$ & Supported \\
\hline Social Value -> Intention & H3 & 0.060 & 0.754 & Not supported \\
\hline Emotional Value -> Intention & H4 & 0.357 & $3.899^{*}$ & Supported \\
\hline Epistemic Value -> Intention & H5 & 0.377 & $5.162 *$ & Supported \\
\hline
\end{tabular}
$* \mathrm{p} \leq 0.05$

\section{Discussion}

The findings showed that conditional value, emotional value and epistemic value contributed positively and significantly on the intention to purchase halal cosmetic products. On the other hand, functional value and social value did not contribute significantly on the intention to purchase halal cosmetic products. The positive significant association between conditional value and intention to purchase a product is in line with the research findings conducted by Mohd Noor and Wen (2016). With regard to this study, it revealed that people intended to purchase halal cosmetic products for special occasions and with the condition that the products are Halal-certified by authorised bodies. This is an assurance that the products have been thoroughly examined in accordance with the rules and regulations.

Furthermore, the outcome on the positive correlation between emotional value and intention to purchase a product is consistent with the research findings by Asshidin et al. (2015). The possible justification found that purchasers perceived fulfilling their happiness and satisfaction from their intention to purchase halal cosmetic products. Additionally, purchasing halal cosmetic products accomplishes one of the Muslims' obligations. Subsequently, the positive significant results on epistemic value and purchase intention are parallel with the research findings by Hur, Yoo and Chung (2012) as they created high curiosity when halal cosmetic products were newly introduced in the market. People purchase these products to gain more information. On the other hand, functional value is not significant on the intention to purchase Halal cosmetic products. These findings were consistent with the research findings of Yang et al. (2017) as it is interpreted that the function of long-lasting cosmetics, safety and quality of the products do not influence customers' purchase intention.

In the same disposition, the social value was found not contributing significantly on the purchasing intention. Indirectly, it showed that customers are not influenced by family, friends and media advertisement to purchase halal cosmetic products. Customers are more concerned about gratifying their Muslim responsibility to purchase Halal products rather than following social attraction in accordance with their surroundings. This shows that other 
components of social influences such as cultural influence across social-ethnic groups affect the intention to purchase Halal cosmetic products as found in the studies by Ajitha and Sivakumar (2017), Kim et al. (2013) and Rahim, Shafii and Shahwan (2015). Hence, the study proves that conditional value, emotional value and epistemic value influence the Muslim women's intention to purchase Halal cosmetic products.

\section{Conclusions}

Currently, the trend of Halal cosmetic products in the global industry is blooming. Thus, producing Halal cosmetic products has drawn many cosmetic manufacturers' attention. The manufacturers need to be alert on the current trend of Halal cosmetic products to remain in this industry. Based on the findings from this study, conditional value is significant on the intention to purchase Halal cosmetics. This implies that manufacturers should produce cosmetics that are certified by an authorised body such as JAKIM. Existing and potential customers will be more confident if the products are certified by an authorised body. The usage of the certification of Halal cosmetic products should be monitored to avoid any misuse. This is consistent with the outcome that epistemic value has a significant relationship with the purchase intention. The procedures, guidelines and regulations on producing and packaging the Halal cosmetic products should be transparent to enable the public to receive precise and up-to-date information. In conjunction with the finding on the positive relationship between emotional value and intention to purchase a product, managers should offer the Halal cosmetic products that are satisfying and convenient to the consumers. For example, the managers may offer an easy wash cosmetic product as it leads to convenience in performing ablution. Coupled with that, they may introduce cosmetic products that can be applied during Muslim prayers after considering the solat regulations. The innovation and development in introducing halal cosmetic products will benefit the Halal market industry and consumers.

Author Contributions: The above mentioned authors have equal contribution to this article write-up.

Acknowledgments: In this segment, you may acknowledge any support that is not addressed by the author's contribution or funding sections. This study received no specific grant or funding from any agency, and was fully funded by the researchers themselves. We would like to express our sincere gratitude to all the respondents who were involved in completing the questionnaire survey for this study.

Conflicts of Interest: The authors declare no conflict of interest in this work.

\section{References}

Ajitha, S., \& Sivakumar, V. J. (2017). Understanding the effect of personal and social value on attitude and usage behaviour of luxury cosmetic brands. Journal of Retailing and Purchaser Services, 39, 103-113. doi:https://doi.org/10.1016/j.jretconser.2017.07.009

Ambali, A.R., \& Bakar, A.N. (2014). People's Awareness on Halal foods and products: Potential Issues for Policy-Makers. Procedia - Social and Behavioral Sciences 121, 3-25. 
Annabi, C. A., \& Obe, O. O. (2017). Halal certification organizations in the United Kingdom: An exploration of halal cosmetic certification. Journal of Islamic Marketing, 8(1), 107-126.

Aoun, I., \& Tournois, L. (2015). Building holistic brands: An exploratory study of Halal cosmetics. Journal of Islamic Marketing, 6(1), 109-132.

Asshiddin, N. H. N, Abidin, N., \& Borhan, H. B. (2016). Perceived quality and emotional value that influence purchasers' purchase intention towards American and local products. Procedia Economics and Finance 35(2016), 639-643. doi:https://doi.org/10.1016/S2212-5671(16)00078-2

Aziz, A., Noor, N. \& Wahab, E. (2013). Understanding of halal cosmetics products: TPB Model.

Baumann, L. (2012). Ethics in cosmetic dermatology. Clinics in Dermatology, 30(5), 522-527. doi:https://doi.org/10.1016/j.clindermatol.2011.06.023

Bonne, K., Vermeir, I., Blackler, F. B., \& Verbeke, W. (2007). Determinants of Halal meat consumption in France. British Food Journal, 109(5), 367-386.

Briliana, V., \& Mursito, N. (2017). Exploring antecedents and consequences of Indonesian Muslim youths' attitude towards halal cosmetic products: A case study in Jakarta. Asia Pacific Management Review, 22(4), 176-184. doi:https://doi.org/10.1016/j.apmrv.2017.07.012

Chin, W. W., Gopal, A, \& Salisbury W. D. (1997). Advancing the theory of adaptive structuration: the development of a scale to measure faithfulness of appropriation. Information System Research, 8(4), 342-367

Fornell, C., \& Larker, D. F. (1981). Evaluating structural equation models with unobservable variables and measurement error. Journal of Marketing Research, 18, 375-381.

Hair, J. F, Black, W. C., Babin, B. J., \& Anderson, R. R. (2010). Multivariate data analysis. Upper Saddle River, NJ: Prentice- Hall.

Hajipour, B., Gharache, M., Hamidizadeh, M.R., \& Mohammadian, F. (2015). Raising Halal cosmetic awareness among the respective purchasers. International Journal of Academic Research in Business and Social Sciences, 5(7), 338-349.

Halal Industry Development Corporation (HIDC). (2017). Retrieved on October 28, 2018 from www.htcglobal.com

Hashim, A. J., \& Musa, R. (2014). Factors influencing attitude towards Halal cosmetic among young adult urban Muslim women: A focus group analysis. Procedia Social and Behavioral Sciences, 130, 129-134.

Hashim, P., \& Hashim, D. (2013). A review of cosmetic and personal care products: Halal perspective and detection of ingredient. Pertanika Journals of Science and Technology, 21(2), 281-292.

Hassan Rahnama. (2017). Effect of consumption values on women choice behaviour toward organic foods: the case of organic yogurt in Iran. Journal of Food Products Marketing, 23(2), 144-166. doi:http://dx.doi.org/10.1080/10454446.2017.1244790

Hassali, M. A., Al-Tamimi, S., Dawood, O. T., et al. (2015). Malaysian cosmetic market: current and future prospects. Pharmaceutical Regulatory Affairs, 4(4), 1-3. doi:http://dx.doi.org/10.4172/2167-7689.1000155

Hur, W. M., Yoo, J. J., \& Chung, T. L. (2012). The consumption values and consumer innovativeness on convergence products. Industrial Management \& Data Systems, 112(5), 688 - 706.

Jalil, N.S.A., Tawde, A.V., Zito, S., et al. (2018). Attitudes of the public towards halal food and associated animal welfare issues in two countries with predominantly Muslim and non-Muslim populations. PLoS ONE 13(10), e0204094 
Kim, J., Han, W. H., Kim, D. T., \& Paramita, W. (2013). Is beauty in the eye of the beholder? Gender and beauty in the cosmetics sectors: A comparative study of Indonesia and Korea. Marketing Intelligence \& Planning, 31(2), 127140.

Kline, R. B. (2011). Principles and practice of structural equation modelling (3rd ed.). New York: The Guiford Press.

Labadie, F. G. (2012). Cosmetic products: Learning to read labels. European Journal of Dermatology, 22(5), 591-595. doi:https://doi.org/10.1684/ejd.2012.1786

Mohd Noor, N. A., \& Wen, T. C. (2016). Assessing purchasers' purchase intention: As hybrid car study in Malaysia. The Social Sciences, 11(11), 2795-2801.

Mukhtar, A., \& Butt, M. M. (2012). Intention to choose Halal products: The role of religiosity. Journal of Islamic Marketing, 3(2), 108-120. doi:http://doi.org/10.1108/17590831211232519

Norafni, F., Zurina, S., \& Syahidawati, S. (2015). Awareness and perception of Muslim purchasers on halal cosmetic and personal care products. International Journal of Business, Economics and Management, 2(1), 1-14.

Rahim, N., Shafii, Z., \& Shahwan, S. (2015). Awareness and perception of Muslim purchasers on Halal cosmetics and personal care products. International Journal of Business, Economics and Management, 2(1), 1-14. doi:http://doi.org/10.18488/journal.62/2015.2.1/62.1.1.14

Rahman, A. A., Asrarhaghighi, E., \& Rahman, S. A. (2015). Purchasers and Halal cosmetics products: Knowledge, religiosity, attitude and intention. Journal of Islamic Marketing, 6(1), 148-163. doi:http://doi.org/10.1108/JIMA09-2013-0068

Ruslan, A. A. A., Kamarulzaman, N. H, \& Sanny, M. (2018). Muslim consumers' awareness and perception of Halal food fraud. International Food Research Journal 25(Suppl.1): S87-S96 (December 2018).

Salleh, M. F. M., \& Hussin, R. (2013). Halal assurance system requirements and documentation in cosmetics industry. In Proceeding of International Conference on Halal Issues and Policies, Makasar, 1-6.

Sheth, J. N., Newman, B. I., \& Gross, B. L. (1991). Why we buy what we buy: A theory of consumption values. Journal of Business Research, 22(2), 159-170. doi:http://doi.org/10.1016/0148-2963(91)90050-8

Yang, K., Kim, J., \& Kim, Y.-K. (2017). The effect of brand consciousness on interpersonal influences, brand values, and purchase intention: Cases for American and Korean college students. Journal of Global Fashion Marketing, 8(2), 83-97. doi:http://doi.org/10.1080/20932685.2016.1274665

Yeo, B. L., Mohamed, R. H., \& Muda, M. (2016). A study of Malaysian customers' purchase motivation of Halal cosmetics retail products: Examining theory of consumption value and customer satisfaction. Procedia Economics and Finance, 37, 176-182. doi:http://doi.org/10.1016/S2212-5671(16)30110-1 